Research Article

\title{
Investigations on DNA damage and frequency of micronuclei in occupational exposure to electromagnetic fields (EMFs) emitted from video display terminals (VDTs)
}

\author{
NK Lakshmi ${ }^{1}$, R Tiwari ${ }^{1}$, SC Bhargava ${ }^{2}$ and YR Ahuja ${ }^{3}$ \\ ${ }^{1}$ UGC Research Unit, Bhavan's New Science College, Hyderabad, Andhra Pradesh, India. \\ ${ }^{2}$ Department of Electrical and Electronic Engineering, Sree Nidhi \\ Institute of Science and Technology, Hyderabad, Andhra Pradesh, India. \\ ${ }^{3}$ Genetics Unit, Vasavi Medical and Research Centre, Hyderabad, Andhra Pradesh, India.
}

\begin{abstract}
The potential effect of electromagnetic fields (EMFs) emitted from video display terminals (VDTs) to elicit biological response is a major concern for the public. The software professionals are subjected to cumulative EMFs in their occupational environments. This study was undertaken to evaluate DNA damage and incidences of micronuclei in such professionals. To the best of our knowledge, the present study is the first attempt to carry out cytogenetic investigations on assessing bioeffects in personal computer users. The study subjects $(n=138)$ included software professionals using VDTs for more than 2 years with age, gender, socioeconomic status matched controls $(n=151)$. DNA damage and frequency of micronuclei were evaluated using alkaline comet assay and cytochalasin blocked micronucleus assay respectively. Overall DNA damage and incidence of micronuclei showed no significant differences between the exposed and control subjects. With exposure characteristics, such as total duration (years) and frequency of use (minutes/day) sub-groups were assessed for such parameters. Although cumulative frequency of use showed no significant changes in the DNA integrity of the classified sub-groups, the long-term users (>10 years) showed higher induction of DNA damage and increased frequency of micronuclei and micro nucleated cells.
\end{abstract}

Key words: electromagnetic fields (EMFs), video display terminals (VDTs), comet assay, DNA damage, micronuclei.

Received: March 25, 2009; Accepted: July 22, 2009.

\section{Introduction}

Electromagnetic technologies like personal computers and televisions have brought social and economic benefits to large sections of society. At the same time, their biological effects are raising concern due to the electromagnetic radiation emitted from video display terminals (VDTs). The video display units comprising cathode ray tube have a large number of applications in all spheres of life like communication and broadcasting, space research and medicine. There is a widespread apprehension that excessive exposure to these electromagnetic fields (EMFs) may hamper fundamental biological processes in the human body.

The potential effects of EMFs on human health vary widely depending on the frequency and intensity of the fields. In spite of years of research, there is still ongoing discussion whether radiofrequency (RF)-EMFs and extremely low frequency (ELF) -EMFs could induce any physi-

Send correspondence to Tiwari Ravindra. UGC Research Unit, Bhavan's New Science College, Narayanguda, Hyderabad, 500029 Andhra Pradesh, India. E-mail: rravindra_tiwari@yahoo.com. ologically relevant effects (Krewski et al. 2007). The studies envisaging the possible health effects of EMF exposure at such field ranges have mainly focused on biological endpoints such as DNA damage (Lai and Singh 1996; Hook et al. 2004; Sun et al. 2006; Yao et al. 2008), increase in free radicals (Tice et al. 2002; Boland et al. 2002; Ferreira et al. 2006; Simko et al. 2006), induction of heat shock proteins (Lantow et al., 2006; Sanchez et al., 2007; Valbonesi et al. 2008) and cellular alterations (Kim et al. 2008; Schwarz et al. 2008).

Relatively less attention has been paid to health hazards from exposure to radiation in the intermediate EMFs, including the radiation emitted from personal computer cathode ray tube monitors, in the frequencies of $20 \mathrm{kHz}$. The workers are subjected to cumulative EMFs in their occupational environments comprising EMFs of $50 \mathrm{~Hz}$ powerline frequencies as well as $15-25 \mathrm{kHz}$ RF-EMFs. Epidemiological studies have suggested that occupational exposure to VDTs is associated with increased risk of various health effects, particularly reproductive disorders, depression and cancer. However, the experimental and epidemiological data from the intermediate frequency (IF) range are 
sparse. Therefore, assessment of acute health risks in the IF range is currently based on known hazards at lower frequencies and higher frequencies.

The conflicting results have raised attention for further research on bioeffects of EMF fields taking into account exposure levels and duration. Apparently very few studies have documented genotoxicity in personal computer users. The present investigation reports DNA damage and chromosomal damage in peripheral blood lymphocytes of the exposed populations by alkaline comet assay or Single Cell Gel Electrophoresis (SCGE) and cytochalasin blocked micronuclei test (CBMN). To the best of our knowledge, there is no report from India on the genotoxic potential of occupational exposure to VDTs. Hence, this study was carried out to investigate the effect of occupational EMFs exposure on DNA damage and frequency of micronuclei in peripheral blood leukocytes of the VDT users. Analysis of the data was carried for all the exposed subjects pooled together as well as in sub-groups based on the duration and intensity effect of exposure.

\section{Subjects and Methods}

\section{Participants}

The study included 138 subjects occupationally exposed to video display terminals for more than two years. The exposed subjects were screened along with 151 age, sex and diet matched controls with similar socioeconomic status. The exposed subjects were software professionals from software companies and consultancies in Hyderabad, India. In the detailed questionnaire, duration of exposure (years), frequency of exposure in hours/day were noted. Age, diet, gender, recent infection, smoking, drinking alcohol and exercise were also recorded for both exposed and unexposed populations.

\section{Sampling}

After taking informed consent, $2 \mathrm{~mL}$ peripheral blood was collected from each participant by venepuncture into heparinised disposable syringe and placed in ice to prevent exogenous damage. The sample was processed in the laboratory within an hour of collection for assessing DNA damage and micronucleus frequency.

\section{Chemicals}

The sources of chemicals were as follows: Agarose [low melting point $\left(20{ }^{\circ} \mathrm{C}\right)$ and regular melting point $\left(35^{\circ} \mathrm{C}\right)$ ], sodium lauryl sarcosinate, Triton X-100, silver nitrate (all from Sigma-USA); tungstosilicic acid(KochLight Laboratories, UK); sodium chloride, sodium hydroxide, potassium chloride, TRIS, EDTA, potassium dihydrogen phosphate and sodium phosphate dibasic (all from Glaxo, Mumbai, India); zinc sulphate and ammonium nitrate (Fisher, Madras, India); thiobarbituaric acid, butylated hydroxyl toluene, sulphosalicyclic acid and N-1-napthyl ethylene diamine dihydrochloride, potassium chloride, methanol, acetic acid (all from SD Fine Chemicals, Mumbai, India); RPMI-1640 media - Himedia, Phytohaemagglutinin - Gibco, Penicillin, Streptomycin - Himedia. Phytohaemagglutinin (PHA), Cytochalasin B (all from Sigma, USA), DMSO - (Merck, Germany).

\section{Alkaline comet assay}

Alkaline comet assay or single cell gel electrophoresis (SCGE) after Singh et al. (1998) was used to study DNA damage.

On a clean, dry, plain slide $100 \mu \mathrm{L}$ of $0.75 \%$ normal melting agarose (NMA) prepared in phosphate buffered saline (PBS) was layered. These precoated slides were dried at $37^{\circ} \mathrm{C}$. On top of this layer, $30 \mu \mathrm{L}$ of whole blood, mixed with $70 \mu \mathrm{L}$ of $0.5 \%$ low melting agarose (LMA) prepared in PBS was layered. The third layer consisted of $100 \mu \mathrm{L}$ of LMA. The slides were incubated in cold lysis buffer $(2.5 \mathrm{M}$ $\mathrm{NaCl}, 100 \mathrm{mM} \mathrm{Na}{ }_{2}$ EDTA, $10 \mathrm{mM}$ Tris; 1\% sodium lauryl sarcosinate; $1 \%$ Triton $\mathrm{X}-100$ and $10 \%$ DMSO added fresh) at $4{ }^{\circ} \mathrm{C}$ overnight.

The slides were removed from the lysing solution and placed side by side in a horizontal electrophoretic unit. The slides were completely immersed in freshly prepared alkaline electrophoretic buffer ( $1 \mathrm{mM} \mathrm{Na}{ }_{2}$ EDTA and $300 \mathrm{mM}$ $\mathrm{NaOH}$; $\mathrm{pH}$ 13) for $30 \mathrm{~min}$ to facilitate the DNA unwinding and expression of alkali labile sites. After alkali treatment, the electrophoresis was carried out for $30 \mathrm{~min}$ at $300 \mathrm{~mA}$ and $0.67 \mathrm{~V} / \mathrm{cm}$. The slides were carefully lifted from the buffer and gently washed with neutralizing buffer $(0.4 \mathrm{M}$ Tris buffer, $\mathrm{pH}$ 7.5). The slides were then washed with distilled water and air dried.

The air dried slides were immersed in the fixing solution $(15 \% \mathrm{w} / \mathrm{v}$ trichloroacetic acid, $5 \% \mathrm{w} / \mathrm{v}$ zinc sulphate and $5 \% \mathrm{w} / \mathrm{v}$ glycerol) for $10 \mathrm{~min}$ and washed gently with double distilled water several times. For staining, $32 \mathrm{~mL}$ of staining solution $\mathrm{A}\left(5 \% \mathrm{w} / \mathrm{v} \mathrm{Na}_{2} \mathrm{CO}_{3}\right)$ was mixed with $68 \mathrm{~mL}$ of staining solution $\mathrm{B}\left(0.02 \% \mathrm{w} / \mathrm{v} \mathrm{NH} \mathrm{NHO}_{3}, 0.02 \%\right.$ $\mathrm{w} / \mathrm{v} \mathrm{AgNO}_{3}, 0.1 \% \mathrm{w} / \mathrm{v}$ tungstosilicic acid and $0.05 \% \mathrm{v} / \mathrm{v}$ formaldehyde) and poured over the slides so as to cover the slides uniformly. This step was repeated until with a fresh mixture of staining solution a grayish colour developed on the slides. To stop staining, the slides were immersed in stopping solution ( $1 \%$ acetic acid) for $5 \mathrm{~min}$, washed with double distilled water and air dried.

For visualization of DNA damage, a bright field, transmission light microscope (Leitz) was used at 400x magnification. Comet tail length was measured, using an ocular micrometer fitted in the eyepiece, in 200 cells per slide (in duplicate). Mean comet tail length, which is an estimate of DNA damage, was calculated for each sample.

\section{Cytokinesis block micronucleus (CBMN) assay}


Micronuclei (MN) were observed in cytokinesisblocked cells using cytochalasin B (Cyt-B) following the method suggested by Fenech and Morley (1985).

About $0.2 \mathrm{~mL}$ of PHA was added to $5 \mathrm{~mL}$ of RPMI 1640 medium using $1 \mathrm{~mL}$ syringe. 15 drops of blood was added to each vial. Samples were initiated in duplicates. The culture vials were incubated for $72 \mathrm{~h}$ at $37^{\circ} \mathrm{C}$ and shaken for proper mixing. Cyt-B $(6 \mu \mathrm{g} / \mathrm{mL})$ was added at $44^{\text {th }}$ hour after initiation of culture and incubated further for another $28 \mathrm{~h}$ at $37^{\circ} \mathrm{C}$ and then cultures were harvested.

The cultures were centrifuged at $1000 \mathrm{rpm}$ for 5-10 min. The supernatant was discarded and $5 \mathrm{~mL}$ of prewarmed hypotonic solution $(0.56 \%)$ was added to the pellet drop by drop slowly on by vortexing and incubated for $10 \mathrm{~min}$ for $37^{\circ} \mathrm{C}$. Then the vials were centrifuged for a minute and supernatant was discarded. Cells were fixed in $5 \mathrm{~mL}$ of fixative (3:1 methanol: acetic acid) followed by two more changes of fixative.

The slides were prepared in triplicate by gently dropping the cell suspension onto the precleaned slides and flame dried. Slides were stained with $2 \%$ Giemsa for $10 \mathrm{~min}$, rinsed and air dried.

To determine the MN yield, nearly 1000 binucleated (BN) cells were scored for each experimental condition under magnifications of 400x and finally 1000x from 2 coded slides/culture. Identification of $\mathrm{MN}$ was according to the criteria summarized by Countryman and Heddle (1976). Routinely on average $\sim 2000 \mathrm{BN}$ cells were scored for the presence of $\mathrm{MN}$ in each subject and mean values of the results were calculated.

\section{Statistical analysis}

The slides were coded during processing and decoded at the time of statistical analysis. For statistical evaluation, observations on each parameter for each group were pooled and mean \pm SD was calculated. Student's t-test (paired and unpaired comparisons) and one way ANOVA were performed to evaluate various differences. Multiple regression analysis was done to study the effects of confounding fac-
Table 1 - General characteristics of the study group and controls.

\begin{tabular}{|c|c|c|c|}
\hline S. n. & Variables & Exposed subjects & Control \\
\hline 1 & Number(n) & 138 & 151 \\
\hline \multirow[t]{2}{*}{2} & Age (range) & $21-47$ & $17-44$ \\
\hline & $($ Mean \pm SD) & $25.13 \pm 4.07$ & $22.88 \pm 4.45$ \\
\hline \multirow[t]{3}{*}{3} & Sex & & \\
\hline & Males & $87(63.04 \%)$ & $101(66.89 \%)$ \\
\hline & Females & $51(36.96 \%)$ & $50(33.11 \%)$ \\
\hline \multirow[t]{2}{*}{4} & Smoking habits & & \\
\hline & Smokers & $32(23.2 \%)$ & $0(0 \%)$ \\
\hline \multirow[t]{2}{*}{5} & Drinking habits & & \\
\hline & Alcoholism & $34(24.6 \%)$ & $0(0 \%)$ \\
\hline \multirow[t]{3}{*}{6} & Dietary habits & & \\
\hline & Vegetarian & $53(38.41 \%)$ & $74(49.01 \%)$ \\
\hline & Non-vegetarian & $85(61.59 \%)$ & $77(50.99 \%)$ \\
\hline
\end{tabular}

tors and correlation analysis was carried out to adjudge the sensitivity of parameters used. Statistical software SPSS 15 was used to carry out statistical analysis.

\section{Results}

The general characteristics of the study group and controls are shown in Table 1 . The mean $( \pm$ SD) duration of VDT use was $7( \pm 4.8)$ years with a mean $( \pm \mathrm{SD})$ cumulative frequency of $389( \pm 147)$ minutes per day.

The results of basal DNA damage assessed by alkaline comet assay in terms of mean comet tail length $\pm \mathrm{SD}$ are summarized in Table 2. Independent $t$ test showed no significant difference in the mean comet tail length values of exposed and controls. The results of CBMN assay on binucleated cells, percentage micronuclei $(\% \mathrm{MN})$ and percentage micronucleated cells $(\% \mathrm{MNC})$ of the exposed groups are shown in Table 3. Overall, there was no significant difference in the frequency of micronuclei between the exposed subjects and the controls (Table 3). However, results

Table 2 - Mean \pm SD values of DNA damage in exposed and control subjects.

\begin{tabular}{|c|c|c|c|c|c|c|}
\hline \multirow[t]{2}{*}{ Parameters } & \multicolumn{2}{|c|}{ Exposed subjects } & \multicolumn{2}{|c|}{ Control } & \multirow[t]{2}{*}{ t value } & \multirow[t]{2}{*}{$\mathrm{p}$ value } \\
\hline & $\mathrm{N}$ & Mean \pm SD & $\mathrm{N}$ & Mean \pm SD & & \\
\hline Comet tail length (arbitrary units) & 138 & $3.76 \pm 1.38$ & 151 & $3.69 \pm 1.13$ & 1.895 & $0.061^{\mathrm{NS}}$ \\
\hline
\end{tabular}

NS: Non-significant at $5 \%$.

Table 3 - Mean \pm SE values of frequency of micronuclei in exposed and control subjects.

\begin{tabular}{lccccc}
\hline Groups & Sample size & Number of BN cells & Total number of micronuclei & Mean \pm SE of MN cells (\%) & Mean \pm SE of MN (\%) \\
\hline IF-EMF & 34 & 35053 & 413 & $1.16 \pm 0.48^{\mathrm{NS}}$ & $1.39 \pm 0.63^{\mathrm{NS}}$ \\
Control & 60 & 64026 & 661 & $1.04 \pm 0.52^{\mathrm{NS}}$ & $1.24 \pm 0.67^{\mathrm{NS}}$ \\
\hline
\end{tabular}

NS: Non-significant at $5 \%$. 
from one-way ANOVA revealed significant differences in DNA damage and incidence of micronuclei among subgroups based on duration of exposure (years) of exposed subjects (Table 4). The significant mean comet tail length and incidences of micronuclei was observed in sub-group having duration of exposure more than 10 years. The two sub-groups based on frequency of exposure $(<420 \mathrm{~min} /$ day and $>420 \mathrm{~min} /$ day) had no significant difference in damage levels (Table 5).

Pearson's coefficient of correlation was carried out between different parameters to assess the extent of relationship between the endpoints of comet assay and CBMN assay (Table 6). The mean comet tail length and frequency of micronuclei showed no significant correlation in the exposed as well the control subjects. Of the various confounding factors studied, no significant effect could be seen in multiple regression analysis with respect to gender, age and habits.

\section{Discussion}

Non-panel video display screens of computer monitors produce significant EMFs despite improvements in

Table 4 - DNA damage and frequency of micronuclei in relation to duration of exposure to VDTs.

\begin{tabular}{|c|c|c|c|c|c|}
\hline \multicolumn{2}{|c|}{ Observation } & \multicolumn{2}{|c|}{$\begin{array}{l}\text { Group based on duration of } \\
\text { exposure (years) }\end{array}$} & \multirow[t]{2}{*}{$t$ value } & \multirow[t]{2}{*}{$\mathrm{p}$ value } \\
\hline & & $1-6$ & $>7$ & & \\
\hline \multirow[t]{2}{*}{ CTL } & $\mathrm{N}$ & 73 & 65 & 21.96 & $<0.001$ \\
\hline & M & $3.15 \pm 0.24$ & $4.09 \pm 0.26$ & & \\
\hline \multirow[t]{2}{*}{$\% \mathrm{MNC}$} & $\mathrm{N}$ & 20 & 14 & 28.39 & $<0.001$ \\
\hline & M & $1.00 \pm 0.19$ & $2.73 \pm 0.15$ & & \\
\hline \multirow[t]{2}{*}{$\% \mathrm{MN}$} & $\mathrm{N}$ & 20 & 14 & 5.80 & $<0.001$ \\
\hline & M & $1.19 \pm 0.24$ & $1.63 \pm 0.18$ & & \\
\hline
\end{tabular}

CTL-comet tail length, MN- micronuclei, MNC- micronucleated cells, $\mathrm{N}$ sample size, M-mean \pm SE.

Table 5 - DNA damage and incidences of micronuclei in relation to frequency of exposure (minutes/day) to VDTs.

\begin{tabular}{llccrr}
\hline Observation & \multicolumn{2}{c}{$\begin{array}{c}\text { Group based on frequency of } \\
\text { exposure (minutes/day) }\end{array}$} & $\begin{array}{c}\mathrm{t} \\
\text { value }\end{array}$ & $\begin{array}{c}\mathrm{p} \\
\text { value }\end{array}$ \\
\cline { 3 - 5 } & & $\begin{array}{c}\mathrm{A} \\
180-420\end{array}$ & $\begin{array}{c}\mathrm{B} \\
420-720\end{array}$ & & \\
\hline $\mathrm{CTL}$ & $\mathrm{N}$ & 64 & 74 & 1.259 & 0.210 \\
& Mean $\pm \mathrm{SE}$ & $3.5991 \pm 0.16$ & $3.8914 \pm 0.17$ & & \\
\hline$\% \mathrm{MNC}$ & $\mathrm{N}$ & 20 & 14 & 1.177 & 0.249 \\
& Mean $\pm \mathrm{SE}$ & $1.2382 \pm 0.11$ & $1.0474 \pm 0.12$ & & \\
\hline$\% \mathrm{MN}$ & $\mathrm{N}$ & 20 & 14 & 1.026 & 0.317 \\
& Mean $\pm \mathrm{SE}$ & $1.5085 \pm 0.14$ & $1.2526 \pm 0.16$ & & \\
\hline
\end{tabular}

CTL-comet tail length, MN- micronuclei, MNC- micronucleated cells, $\mathrm{N}$ sample size, M-mean \pm SE.
Table 6 - Pearson's correlation analysis in exposed and control subjects.

\begin{tabular}{llll}
\hline Group & CTL & $\% \mathrm{MN}$ & $\% \mathrm{MNC}$ \\
\hline $\begin{array}{l}\text { Exposed } \\
\mathrm{CTL}\end{array}$ & & & \\
$\% \mathrm{MN}$ & 0.002 & 0.002 & 0.026 \\
$\% \mathrm{MNC}$ & 0.026 & $0.977^{* *}$ & $0.977^{* *}$ \\
\hline Control & & & \\
$\mathrm{CTL}$ & & 0.03 & 0.04 \\
$\% \mathrm{MN}$ & 0.03 & & $0.70^{* *}$ \\
$\% \mathrm{MNC}$ & 0.04 & $0.70^{* *}$ & \\
\hline
\end{tabular}

**Correlation is significant at the 0.01 level (2-tailed).

technology over the last decade or so. In India presently there is a boom in Information Technology (IT) and Business Process Outsourcing centers. The IT sector witnessed considerable activity since 2004 including a ramping up of operations by major multinational corporations. Apart from the powerline frequencies (ELF-EMFs) the software employees are exposed to EMFs emitted from personal computers.

The workers are subjected to cumulative EMFs in their occupational environments. To the best of our knowledge, the present study is the first attempt to carry out multiple markers on assessing bioeffects in subjects occupationally exposed to Cathode Ray Tube (CRT) from personal computers. The aim of our study was to investigate genotoxicity in workers occupationally exposed to CRT VDTs through the induced DNA damage and micronuclei in leukocytes and lymphocytes respectively.

Overall, the results on DNA damage and micronuclei frequency showed no significant differences. With exposure characteristics, such as total duration (years) and frequency of use (minutes/day), sub-groups were also assessed for such parameters. The long-term users $(>10$ years) showed higher induction of DNA damage and increased frequency of micronuclei and micronucleated cells. The cumulative frequency of use showed no significant changes in the DNA integrity between the classified subgroups.

The subjective symptoms reported by the PC usage include predominantly headache, followed by sleeplessness and neck pain. Duration and intensity was not significant predicting factors for the reported symptoms. Very few in vivo studies have directly evaluated the cytogenetic damage in computer workers. Carbonari et al. (2005) indicated significant cytogenetic damage by micronuclei assay in computer workers, reinforcing the data obtained in our study. Estecio and Silva (2002) also evaluated possible nuclear alterations in microcomputer's workers and found that exposed individuals had two times more chromosomal aberrations in cultured lymphocytes than control individuals. The rationale behind such findings have been proposed to be the genotoxic influences of EMFs may be through in- 
creased free radical activity or acceleration of electron transfer in different enzymes and proteins.

In the present study, no thermal effects of EMFs could be seen. However, Gangi and Johansson (2000) detected an increased incidence of skin and central nervous system (CNS) alterations among microcomputer workers. Andersson (1996) reported that female workers exposed to VDU presented obstetric complications, besides skin, ocular and CNS diseases.

Thus we conclude that this epidemiological study on occupational EMF exposure was significant to provide preliminary evidence on health risk along with the pertinent reliable parameters carried out as biomarkers. The longtermed effect also implicated the need for close monitoring of health hazards associated in long-term VDT users.

\section{Acknowledgments}

The authors acknowledge the financial assistance from Union Grants Commission India.

\section{References}

Andersson B (1996) A cognitive-behavioral treatment of patients suffering from "electric hypersensitivity". Subjective effects and reactions in a double-blind provocation study. $\mathrm{J}$ Occup Environ Med 38:752-758.

Boland A, Delapierre D, Mossay D, Dresse A and Seutin V (2002) Effect of intermittent and continuous exposure to electromagnetic fields on cultured hippocampal cells. Bioelectromagnetics 23:97-105.

Carbonari K, Goncalves L, Roth D, Moreira P, Fernández R and Martino-Roth MG (2005) Increased micronucleated cell frequency related to exposure to radiation emitted by computer cathode ray tube video display monitors. Genet Mol Biol 28:469-474.

Countryman PI and Heddle JA (1976) The production of micronuclei from chromosome aberrations in irradiated cultures of human lymphocytes. Mutat Res 41:321-332.

Estecio MRH and Silva AE (2002) Chromosome abnormalities caused by computer video display monitor's radiation. Rev Saude Publica 36:330-336.

Fenech M and Morley AA (1985) Measurement of micronuclei in lymphocytes. Mutat Res 147:29-36.

Ferreira AR, Knakievicz T, Pasquali MA, Gelain DP, Dal-Pizzol F, Fernández CE, de Salles AA, Ferreira HB and Moreira JC (2006) Ultra high frequency electromagnetic field irradiation during pregnancy leads to an increase in erythrocytes micronuclei incidence in rat offspring. Life Sci 80:43-50.

Gangi S and Johansson O (2000) A theoretical model based upon mast cells and histamine to explain the recently proclaimed sensitivity to electric and/or magnetic fields in humans. Med Hypoth 54:663-671.
Hook GJ, Zhang P and Lagroye I (2004) Measurement of DNA damage and apoptosis in Molt-4 cells after in vitro exposure to radiofrequency radiation. Radiat Res 161:193-200.

Kim TH, Huang TQ, Jang JJ, Kim MH, Kim HJ, Lee JS, Pack JK, Seo JS and Park WY (2008) Local exposure of $849 \mathrm{MHz}$ and $1763 \mathrm{MHz}$ radiofrequency radiation to mouse heads does not induce cell death or cell proliferation in brain. Exp Mol Med 40:294-303.

Krewski D, Glickman BW, Habash RW, Habbick B, Lotz WG, Mandeville R, Prato FS, Salem T and Weaver DF (2007) Recent advances in research on radiofrequency fields and health: 2001-2003. J Toxicol Environ Health 10:287-318.

Lai H and Singh NP (1996) Single- and double-strand DNA breaks in rat brain cells after acute exposure to radiofrequency electromagnetic radiation. Int J Radiat Biol 69:513-521.

Lantow M, Lupke M, Frahm J, Mattsson MO, Kuster N and Simko M (2006) ROS release and Hsp 70 expression after exposure to $1800 \mathrm{MHz}$ radiofrequency electromagnetic fields in primary human monocytes and lymphocytes. Radiat Environ Biophys 45:55-62.

Sanchez S, Haro E, Ruffié G, Veyret B and Lagroye I (2007) In vitro study of the stress response of human skin cells to GSM-1800 mobile phone signals compared to UVB radiation and heat shock. Radiat Res 167:572-580.

Schwarz C, Kratochvil E and Pilger A (2008) Radiofrequency electromagnetic fields (UMTS, 1,950 MHz) induce genotoxic effects in vitro in human fibroblasts but not in lymphocytes. Int Arch Occup Environ Health 81:755-767.

Simko M, Hartwig C, Lantow M, Lupke M, Mattsson MO, Rahman Q and Rollwitz J (2006) Hsp 70 expression and free radical release after exposure to non-thermal radio-frequency electromagnetic fields and ultrafine particles in human Mono Mac 6 cells. Toxicol Lett 161:73-82.

Singh NT, McCoy NT and Tice RR (1998) A simple technique for quantification of low levels of DNA in individual cells. Exp Cell Res 517:184-191.

Sun LX, Yao K and He JL (2006) Effect of acute exposure to microwave from mobile phone on DNA damage and repair of cultured human lens epithelial cells in vitro. Zhonghua Lao Dong Wei Sheng Zhi Ye Bing Za Zhi 24:465-467.

Tice RR, Hook GG and Donner M (2002) Genotoxicity of radiofrequency signals. I. Investigation of DNA damage and micronuclei induction in cultured human blood cells. Bioelectromagnetics 23:113-126.

Valbonesi P, Franzellitti S, Piano A, Contin A, Biondi C and Fabbri E (2008) Evaluation of HSP70 expression and DNA damage in cells of a human trophoblast cell line exposed to $1.8 \mathrm{GHz}$ amplitude-modulated radiofrequency fields. Radiat Res 169:270-279.

Yao K, Wu W, Wang K, Ni S, Ye P, Yu Y, Ye J and Sun L (2008) Electromagnetic noise inhibits radiofrequency radiation-induced DNA damage and reactive oxygen species increase in human lens epithelial cells. Mol Vis 14:964-969.

\section{Associate Editor: Catarina S. Takahashi}

License information: This is an open-access article distributed under the terms of the Creative Commons Attribution License, which permits unrestricted use, distribution, and reproduction in any medium, provided the original work is properly cited. 